\title{
課題スイッチコストと手掛りスイッチコストへの構音抑制の効果
}

\author{
○佐伯恵里奈 ${ }^{12}$. 齊藤智 2 \\ ( ${ }^{1}$ 日本学術振興会 $・ 2$ 京都大学大学院教育学研究科) \\ キーワード: 言語的表象 タスクスイッチング 課題セット検索
}

\author{
Differential effects of articulatory suppression on cue-switch and task-switch costs \\ Erina SAEKI ${ }^{12}$ and Satoru SAITO ${ }^{2}$ \\ $\left({ }^{1} \mathrm{JSPS},{ }^{2}\right.$ Graduate School of Education, Kyoto University)
}

Key words: verbal representation, task switching, task-set retrieval

日常生活を円滑に営むには、内的な意図や外的な合図に基 づいて、柔軟に課題を変更することが不可欠であり、この課 題変更に関わる認知過程を検証寸るため考案された実験課題 が、タスクスイッチングである。タスクスイッチングの遂行 中に無関連な語の構音を求めることで、音韻/言語的表象の利 用を妨害する構音抑制法を用いた研究から、この課題の遂行 に言語的表象が関与していることが示されている。例えば、 刺激毎に手掛りを呈示して、手掛りによりランダムに課題の スイッチと繰り返しを求めるランダム手掛り法を用いた場合 手掛りが課題を直接明示しない場面で、構音抑制はスイッチ 試行の反応時間を遅延し、スイッチコストを増加することが 報告されている。スイッチコストとは、スイッチ試行の RT からリピート試行の RT を引くことにより算出される、スイ ッチ処理に必要な認知過程を反映する指標であり、スイッチ コストへの構音抑制の干渉効果は、言語的表象が課題スイッ チに必要な認知過程に関与することを示唆している。一方、 外的な掛りがない場面で、2 試行毎に系列的に課題をスイッ チ寸る場合には、構音抑制の干渉効果は、課題の変更が必要 な試行だけでなく、課題を繰り返す場面でも認められる。こ の結果は、言語的表象が課題スイッチ処理自体ではなく、む しろ、系列情報の制御に関与していることを示唆している。

本研究では、課題スイッチ処理自体への言語的表象の関与

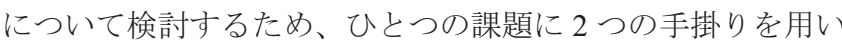
たランダム手掛り法による実験を行った。この方法により、 手掛りは変更されるが課題は変更されない「手掛りスイッチ

一課題反復試行」と、手掛りも課題も変更される「手掛りス イッチ - 課題スイッチ試行」を区分することができる。先行 研究で示された、ランダム手掛り法でのスイッチコストへの 構音抑制の干渉効果が、課題スイッチ処理ではなく、手掛り から課題を検索するための処理を妨害したことによるものだ とすれば、手掛りは変更されるが課題の変更は必要ない「手 掛りスイッチ - 課題反復試行」でも構音抑制の干渉効果が示 されると予測される。実験 1 では、課題検索負荷の高い、恣 意的なシンボリック記号を手掛りに用いた。実験 2 では課題 と意味的に関連する漢字を用いることにより、手掛りが課題 を明示する場面での構音抑制の干渉効果を検討した。

\section{方 法}

手掛り以外は、実験 $1 \cdot 2$ で同じ刺激・課題・手続きが用いられた。 実験参加者: 実験 1 は 24 名、実験 2 は 18 名の大学生。刺激 ・ 課題 : 赤あるいは緑の長方形に、丸あるいは三角の図形が描 かれたターゲット刺激が呈示され、手掛りに従って、色判断 (赤・緑) と形判断（三角・丸）をキー押しによって判断する ことが求められた。実験 1 には怨意的な 4 つの記号である

\section{Q to oto 8}

が手掛りとして用いられた。実験 2 では、

色判断には「色・彩」、形判断には「形・型」の合計 4 つの漢 字が手掛りとして用いられた。手掛り - 刺激閒隔は $300 \mathrm{~ms}$ 、
反応 - 手掛り間隔は $1200 \mathrm{~ms}$ であった。手続き：参加者は最 初にそれぞれの課題と反応キーの練習、続いて、手掛りと課 題についての練習を行った。その後、本課題が実施され、ラ ンダムに「手掛り - 課題反復試行」、「手掛りスイッチ - 課題 反復試行」、「手掛りスイッチ - 課題スイッチ試行」が 18 試行 ずつ含まれている合計 48 試行 (と分析から除外される 1 試行) からなるブロックを統制条件、構音抑制条件、タッピング条 件で 3 ブロックずつ遂行した。構音抑制条件では 0.5 秒に 1 回のペースでダを構音することが、タッピング条件では、同 じペースで足をタップすることが求められた。

\section{結 果}

実験 1 の RT につい、試行タイプ（3）×遂行条件（3） の分散分析を実施した。その結果、試行タイプの主効果が有 意であり, $F(2,46)=24.26, p<.01$, 寸心゙ての遂行条件で手掛りス イッチ - 課題スイッチ試行、手掛りスイッチ - 課題反復試行、 手掛り - 課題反復試行の順に RT が長いことが示された。遂 行条件の主効果も有意であり, $F(2,46)=12.92, p<.01$, 試行夕 イプ×遂行条件の交互作用も有意であった, $F(4,92)=2.84, p$ $<.05$ 。手掛り - 課題反復試行では構音抑制とタッピングに有 意な違いは認められなかったが、手掛りスイッチ - 課題反復 試行では構音抑制条件の RT がタッピングよりも有意に長く、 また手掛りスイッチ - 課題スイッチ試行では、構音抑制条件 のRTがタッピング条件よりも有意に長い傾向が認められた。

実験 2 の RT について、実験 1 と同様に、試行タイプ (3) ×遂行条件（3）の分散分析を実施した結果、遂行条件による RT の違いは認められず、試行タイプの主効果のみ有意であっ た, $F(2,34)=26.78, p<.01 。 \mathrm{RT}$ は 手掛りスイッチ - 課題スイッ 于試行、手掛りスイッチ - 課題反復試行、手掛り - 課題反復 試行の順に長いことが示された。

Table 1. Mean RTs for different trials in each condition in Exp 1 \&2

\begin{tabular}{llccc} 
& & Control & Articulation & Tapping \\
\hline Exp. 1 & Cue repeti & 531.92 & 649.56 & 608.27 \\
& Cue-switch & 606.27 & 754.06 & 645.37 \\
& Task-switch & 741.63 & 842.37 & 772.54 \\
Exp. 2 & Cue repeti & 496.12 & 503.64 & 502.86 \\
& Cue-switch & 514.93 & 528.23 & 537.42 \\
& Task-switch & 581.20 & 593.23 & 585.29 \\
\hline \multicolumn{4}{c}{ 考 察 }
\end{tabular}

怨意的な記号を手掛りに用いた実験 1 では、手掛りが変更 されるが実際に課題の変更は求められない試行でも、構音抑 制が反応時間を遅延することが示された。このことは、ラン ダム手掛り課題への構音抑制の干渉効果は、実際の課題スイ ッチ処理よりむしろ、手掛りから課題を検索する過程を妨害 していることを示唆している。手掛りに課題と意味的関連が 強い漢字を使用することで、課題検索負荷を軽くした実験 2 では構音抑制の影響が認められないという結果は、この可能 性を支持するものと思われる。（Erina SAEKI, Satoru SAITO） 